Anton Puškarić1

Boris Kuzman ${ }^{2}$

Institute of Agricultural Economics, Belgrade

Branka Maksimović ${ }^{3}$

Higher School of Professional Business Studies, Novi Sad
SCIENTIFIC REVIEW ARTICLE doi:10.5937/ekonomika1604085P

Received: October 10, 2016

Accepted: November 16, 2016

\title{
IMPACT OF PROMOTIONAL ACTIVITIES ON THE DEVELOPMENT OF AUTOCHTHONOUS FOOD PRODUCTS MARKET
}

\begin{abstract}
Consumers who eat industrial food products often forget traditionally produced food. In this case, it is necessary to remind consumers on already well-known products through series of promotional activities, i.e. get them familiar with the advantages implied by their consumption. The goal of this paper is to point out to the significance of promotional activities for the development of autochthonous food products market. A consumer is informed by the promotion, he/she forms a positive attitude, which represents an important influence on a decision whether to buy autochthonous food products.

While planning the autoch thonous food products promotion, it is necessary to choose activities that are going to be implemented. Regarding that autochthonous food products are the subject of the research, the special significance have the improvement of sale, personal sale and publicity which enable the communication to potential consumers. Other promotional activities are also significant. It is important to emphasize that coordinated or united activity of the promotional mix selected instruments represents an imperative for a successful promotion of autochthonous food products.
\end{abstract}

Key words: promotion, autochthonous food products.

JEL Classification: Q13

\section{УТИЦАЈ ПРОМОТИВНИХ АКТИВНОСТИ НА РАЗВОЈ ТРЖИШТА АУТОХТОНИХ ПРЕХРАМБЕНИХ ПРОИЗВОДА}

\section{Апстракт}

Потрошачи, који се хране индустријским прехрамбеним производима, често забораве на прехрамбене производе који су произведени на традиционалан начин. У том случају потребно је, помоћу низа промотивних активности, потрошаче подсетити на већ познате производе, односно упознати их са предностима које юихово конзумирање подразумева. Циљ рада је да се

\footnotetext{
${ }^{1}$ anton.puskaric@gmail.com

${ }^{2}$ kuzmanboris@yahoo.com

${ }^{3}$ branka.maksimovic.vps@gmail.com
} 
укаже на значај промотивних активности за развој тржсита аутохтоних прехрамбених производа. Путем промочије, потрошач се информише, формира позитиван став, ито представља значајан утицај на одлуку о куповини аутохтоних прехрамбених производа.

При планирању промоиије аутохтоних прехрамбених производа потребно је одабрати активности које ће бити применене. С обзиром да су предмет истраживања аутохтони прехрамбени производи, посебан значај имају унапређење продаје, лична продаја и публицитет који омогућавају комуникацију потенцијалним потрочачима. Такође, и друге промотивне активности немају мањи значај. Важно је поменути да координирано, односно обједињено, деловање одабраних инструмената промоционог микса представља императив успешне промочије аутохтоних прехрамбених произво$\partial a$.

Кључне речи: промоција, аутохтони прехрамбени производи

\section{Introduction}

Autochthonous food products are significant, because there realizes, by their production, an added value in regard to similar industrially produced food products. These products have the characteristics which separate them from the industrial products. According to an added value they achieve a high price on the market, while consumers have satisfaction by their production.

Depending on a region, i.e. a local area where the production realizes, the products have different characteristics. Promotion of the characteristics which characterise the specific autochthonous products can have multiple benefits. Besides a profit made by selling the autochthonous products, there also promotes a locality related to the production of these products.

The promotions in form of events which represent a series of manufacturers of a specific type of autochthonous food products are especially important, and in that unobtrusive way, often followed by a cultural program, they promote products characteristic for that region, i.e. for the specific locality. The autochthonous products are cultural heritage of the specific locality and they promote it in the traditional and characteristic way.

\section{Results and discussions}

The need for satisfying the realistic expectations of interest defined groups of enthusiasts to share their knowledge and skills in the production of autochthonous food products is obvious. It is necessary to analyse the possible ways, acceptable social educations, aiming to hasten their openness towards challenges offered by the market itself. Herewith an interest group must not at all be put into position to think that possibly adjustment to new trends and commercialization of their cultural norms of behaviour, acquired by tradition, will be discredited in self-respect, to which every source-oriented 
group aspires. The population mobility has helped the cognition of breeding/growing standards and the development of varieties and manufactured products, based on tradition. Specific characteristics of geographic origin of autochthonous varieties in plant, spices production, which use in diet and preparation of manufactured products, have contributed to the dissemination of knowledge of specific features of nutritional and organoleptic characteristics of autochthonous meat products.

It is inevitable to recognize and especially to consider and analyse the marketing possibilities and accordingly to redesign and adjust the marketing systems, conceptions and strategies of positioning and differentiation of production to the interest environment characteristics. Demographic data, ethnicity, cultural, traditional background, collected by a comparative method of population diversity analysis and their quantitativelyexpressed features and specific features, aim to recognise the causal-consequential factors which objectively affect the creation of a demographic profile of the population. According to a demographic structure of a population group, it is possible to outline the process of planning, organization and control of a marketing mix concept, in that way that the attractive and unattractive, decreasing and increasing production and sales opportunities can be determined.

Geographic parameters, defined by topographical features and climate, the historical and cultural identity don't allow the changes in traditional, cultural and specific pattern of behaviour and habits of population. The population on different geographic regions have different needs and habits in the production and preparation of the specific food products. Nowadays, the traditional technologies complete with modern technologies in food production and they not in any way diminish the elemental features of autochthonous products. Food production is becoming more and more diverse and the economy of scale is greater, and therefore it is inevitable to balance supply and demand. Demand is no more caused by emotions, but the consistent quality of specific tastes, nutritional characteristics with all elements of prestige.

In order to increase the demand for autochthonous products, although it already exists, it is necessary to legalize production and implement the necessary veterinarianhealth control and achieve as higher as possible level of standardization, especially of meat manufactured products. Vlahovic and associates (2010) stated that the production of autochthonous products must be on a high level of hygiene, along with the application of modern technology, but with the dominant elements of tradition.

In order to reduce uncertainty and eventual suspicion of potential buyers, it is necessary to make efforts to find a way to actualise the specificity of taste, searching for physical indicators of a manufactured product quality. Selection of elements, which will be necessary to use while trying to concretize the organoleptic effectiveness, provide availability and sale of products, and in that way bring closer to a target group, comes down to: first, a name of an autochthonous product will be chosen, that will point out to quality and will be easy to remember; then, letters, mark and logo will be designed; a slogan will be chosen, which will complete the name of product, emphasize the geographic origin, name of the region and location, and all these will be protected, along with the previous adjustment with the national legislation, after the EU recommendations, and then the geographic origin will be ensured.

The geographic origin protection of products represents an important part of the EU Stabilisation and Association Agreement, which refers to agriculture and food 
industry. EU expects from Serbia to protect its original products and register them after the group regulations. Many EU member-countries make conditions in order to protect particularities in agricultural production and food industry, by the method well-known as the geographic origin. Protection of geographical indication is very important tool for the development of a region, especially rural areas and it represents the opportunity for Serbian manufacturers of traditional products to brand their product by using this protection and, in that way, to increase competitiveness (higher selling price, recognition on the market) (Paraušić and associates, 2007).

From the autochthonous products production point of view, there is no great number of protected designations of origin registered in the Republic of Serbia. In Table 1 are shown only some of the protected designations of origin.

The geographical indications, according to the Law on Geographical Indications (,,Official Gazette of $R S^{\prime \prime}$, no. 18/2010), use for marking the natural, agricultural and industrial products, home craft products and services. The geographical indication is an indication which identifies a specific product as a product from the territory of a specific country, region or locality, where the specific quality, reputation or other characteristics of products can essentially be attributable to their geographical origin and which production and/or processing and/or preparation is realised on the specific limited area. The geographical indication is also the name which is not the geographical name of a certain country, region or locality, but which has become generally known, by its long-lasting use in turnover, as the traditional name of a product from this area. In order to register the geographical indication, it is necessary to submit an application to Intellectual Property Office. The application implies the following: 1) description of a geographic area, 2) data on the specific products characteristics (data on method and procedure of production, data on special features and quality of products, 3) authorised organisations which carry out the control of products quality.

Table 1:List of selected protected geographical indications of autochthonous food products registered in the Intellectual Property Office of $R S$

\begin{tabular}{|l|l|l|l|}
\hline $\begin{array}{l}\text { Beef prosciuto } \\
\text { (smoked ham) from }\end{array}$ & $\begin{array}{l}\text { Pork prosciuto from } \\
\text { Uzice }\end{array}$ & Bacon from Uzice & $\begin{array}{l}\text { Srem paprika- } \\
\text { flavoured sausage }\end{array}$ \\
\hline $\begin{array}{l}\text { Homemade sausage } \\
\text { from Srem }\end{array}$ & $\begin{array}{l}\text { Krivovir kashkaval } \\
\text { cheese (type of hard } \\
\text { cheese) }\end{array}$ & $\begin{array}{l}\text { Homolje sheep-milk } \\
\text { cheese }\end{array}$ & $\begin{array}{l}\text { Homolje goat-milk } \\
\text { cheese }\end{array}$ \\
\hline $\begin{array}{l}\text { Homemade aivar } \\
\text { from Leskovac }\end{array}$ & Petrovac sausage & $\begin{array}{l}\text { Pork cracklings from } \\
\text { Valjevo }\end{array}$ & Wine Bermet \\
\hline $\begin{array}{l}\text { Kashkaval from } \\
\text { Svrljig }\end{array}$ & $\begin{array}{l}\text { Sheep-milk cheese from } \\
\text { Sjenica }\end{array}$ & $\begin{array}{l}\text { Cow-milk cheese } \\
\text { from Sjenica }\end{array}$ & $\begin{array}{l}\text { Kashkaval from Stara } \\
\text { Planina }\end{array}$ \\
\hline $\begin{array}{l}\text { Cow-milk kashkaval } \\
\text { from Pirot }\end{array}$ & $\begin{array}{l}\text { Cabbage and sauerkraut } \\
\text { from Futog }\end{array}$ & Honey from Homolje & $\begin{array}{l}\text { Linden honey from } \\
\text { Fruska Gora }\end{array}$ \\
\hline Kacer honey & $\begin{array}{l}\text { Lemes paprika-flavoured } \\
\text { sausage }\end{array}$ & Vrsac ham & Zlatar cheese \\
\hline
\end{tabular}

Source: Intellectual Property Office, Republic of Serbia 
A manufacturer will found the veracity of tradition and originality in consumers by this relation towards its autochthonous product; then, he will engage experts, skilled and attentive people, who will help building the awareness on a product and a product's image. These elements suggest quality and often make that a product, as well as its benefits, become preferable and tangible.

A consumer analyses and assesses a set of products before he buys, based on their qualitative characteristics, organoleptic specificities, value-nutritional indicators, but also originality. The product is expected to satisfy a need and a certain benefit, which will develop a set of beliefs about brands, which furthermore makes a brand image.

Striving to a consistent quality of a product, and taking into consideration an evident potential for stability and effectiveness of a product, manufacturers try to resort to the quality standardization, which, despite the aforementioned, contains also the concept of development and promotion of products as the possibilities for good advertising of a national or regional brand. The concept of promotion comprises the process of providing logistical support with goals and possible difficulties, and keeps tracking consumers' satisfaction via surveys, where they express their perceptions in forms of complaints and suggestions.

With the rational analysis of all relevant, continuously collected data and information, the marketing experts by coordinated functioning of all available processing departments, get to know with the needs of consumers, primarily, by perceiving the impact of qualitative and specific stimulus on buyers' decisions whether to buy or not. According to the conclusions of an analysis, they will faster, more efficient and more effective bring the marketing decision and establish easier the integrated marketing communication aiming to stimulate sale.

Costs which follow the promotion, depending on the results they want to achieve, can be high. In order to implement successfully the promotion, it is not desirable that planned segments of a promotional mix miss, or to be less present. This exactly can be the case if there is unsufficient budget for the implementation of an entire promotion plan. As it was previously mentioned, the promotional activities must be coordinated, i.e. to be unified, in order to accomplish the full promotion effect.

Association of manufacturers imposes itself as the solution of the problem, based on common characteristics of products or localities, and then also financing the promotional activities aiming to achieve mutual goals.

Communion in the promotion implies an implemented system of products quality, as a guarantee of the unique products quality of all manufacturers within the association. This especially refers to manufacturers who joined according to the same products promotion. If there promotes a certain autochthonous food product with known features, which is related to a specific locality (for example, sausage from Petrovac, cheese from Sjenica), a buyer has to be sure that he well get a product with the same organoleptic features with every purchase and there won't be any quality fluctuations.

The promotion goals are that the potential consumers become familiar with products, as well as that the old consumers remind themselves on the specific products they have already consumed. Important form of promotion represents events, related to a particular type of food product. Most frequently these are meat manufactured products, but also the products which are fruit and vegetable manufactured products. There are significant numbers of events on the territory of the Republic of Serbia, related to one 
or more food products which are prepared in a traditional way. Most of events have the maintaining tradition of over ten years, and the most famous are:

Sausage-event in Turija - international festival of sausages, which is held once a year in the village Turija, located in Backa. The festival has more than 10,000 visitors every year. Main attraction of every Sausage-Event is the sausage longer than $2 \mathrm{~km}$. The length of the sausage is extended for 1 meter every year and in that way the Guinness record is broken every year. This event holds every year in February.

Srem sausage-event - Srem sausage-event is the cultural-gastronomic event, which organizes in Sid, in February. The event lasts for two days. On the first day, there organizes the competition in butchery preparation and processing of Srem homemade sausage in a traditional way, while on the second day, the experts commission assess dry Srem homemade sausages.

Srem Paprika-Flavoured-Sausage-Event. It holds in May, in Erdevik, in the vicinity of Sid. This event is characteristic by a fact that, while evaluating, there treats particularly paprika-flavoured-sausage produced in a natural intestine, and particularly paprika-flavoured-sausage produced in an artificial intestine. It is also important to mention that a manufacturer of best paprika-flavoured-sausage in a natural intestine becomes an absolute winner of the Srem paprika-flavoured-sausage event.

Prosciutto-event in Mackat is the traditional Fair of delicatessen in Mackat, which holds every year in January. The prosciutto event is the traditional competition fair of delicatessen, which holds every year in January in the village Mackat, in the vicinity of Uzice and Zlatibor. The best Serbian delicatessen are chosen at the fair, and around 20 manufacturers represent beef, pork and sheep prosciutto, bacon and sausage from Uzice.

Cabbage-event in Futog is the event which is held for many years in Futog and it promotes the traditional dishes whose main ingredient is cabbage. The original cabbage from Futog has been grown in this region for over 250 years.

Cabbage-event in Mrcajevci is the event which has been hold in Mrcajevci since the year 2003. The competition in preparing the ,wedding cabbage"in a crock, numerous competitions of agricultural character along with the rich cultural program is realised within the bacon-event. It lasts for three days and holds every year, every third weekend in September.

Bacon-event in Kacarevo has been hold in the village of Kacarevo for more than two decades. It is the fair of bacon, meat and meat products. Various competitions take place within the bacon-event, such as the competition in cooking stew „Zlatni kotlic“, rendering of bacon „Zlatni cvarak“, pig slaughter in a traditional way, grabbing suckling pig from a sack, which represents an additional program of this event.

Barbecue-event in Leskovac has been held every year in Leskovac, at the beginning of September and it has beenlasting for seven days. During this event, the most diverse barbecue culinary specialties are prepared. It is on the top of Serbian tourist event, with around 300,000 visitors per a year. What is characteristic for this event is that the biggest burgers are prepared on it, and they compete in beating previous records within the Guinness' book of records. Besides, there the competition in fast eating of hot red peppers is held.

Strudel-event in Novo Milosevo is the traditional cultural-tourist event, which has been holding every July in Novo Milosevo. Among other things, the record in strudel length breaks every year. Besides, the competition for the best strudel holds, as well as the competition in fast eating of strudels. 
Festival of yeast cake with raisins is the first such festival which has been held since the year 2002. This event's goal is to preserve and popularize the yeast cake with raisins, which used to make on the territory of Vojvodina.

Fair of plums in Osecina. The traditional fair of plums is held in the centre of plum production, in Valjevo. The fair is a commercial-tourist and cultural-entertaining event which aims to make a Serbian brand out of plum. From the promotion point of view, it is significant that plum-based manufactured products, manufactured in a traditional way, are exhibited at the fair.

The promotion is necessary to direct to target consumers. Production of autochthonous food products is limited, and thereby there is greater opportunity for the promotion budget to be limited. From the aspect of autochthonous food products promotion, the specific instruments of a promotional mix stand out by their significance and the priority application. Improvement of sales, publicity and personal selling are the instruments of a promotional mix which can stand out in regard to an amount of financial resources that are possible to set aside for the promotion of autochthonous food products.

Encouraging sales is inevitable to implement through promotions, i.e. by tasting products on the counters. The promotions can organise in the facilities visited by many people, who come to buy (markets), but also in busy areas, such as pedestrian zones in the cities. In this case, it is necessary that there is also the possibility for sale if the reaction of a potential buyer, after tasting the product, is positive and if there is a need for buying.

\section{Conclusion}

The development of rural areas is stimulated by the production and sale of autochthonous food products, along with the preservation of national identity and there enriches the region's supply. Autochthonous food products, besides the sociological have also the economic significance, which reflects in competitiveness, profitability of manufacturers, which perceive the performance from consumers' satisfaction point of view. The specific associations (traditional, domestic, natural, etc.) can create an added value while placing at the domestic market. Based on added value, these products achieve a higher price on the market, while consumers are satisfied with their consumption. Higher production and supply increase the competitiveness, which have a positive effect on the increase of quality.

Designed with style and tastily, intriguing defined strategy of the promotional activity forms the consumers' positively balance attitude, with a present dose of emotional satisfaction. Promotional activities get their significance and base future cooperation between manufacturers and consumers. Exactly the continuance of their interactive coordinative cooperation, in sense of desires and possibilities for their fulfilment, justify the engagement of cumulative intellectual and resource potentials of marketing promotional efforts. Manufacturers enjoy in presenting almost forgotten products, while consumers expose the reflection of their pleasure by the aspiration for more frequent encounters with products of such representative and nutritional-qualitative level. However, with all respect of such stimulating events, which find their sponsorship also in the local authorities, in the interest of tourist organizations due to their peculiarity and 
which promotionally represent a locality, region, there should point out to the necessity of standardization of forms, shapes and uniformity of autochthonous products tastes.

\section{References}

Babović, J., Nikolić, A., Raičević, V. (2013): Neki aspekti marketinga organskih prehrambenih proizvoda, Economic Themes, Vol. 51 Issue 1, p.p. 173-189.

Bianka Kühne, B., Vanhonacker, F., Gellynck, X., Verbeke, W. (2010): Innovation in traditional food products in Europe: Do sector innovation activities match consumers' acceptance?, Food Quality and Preference, Volume 21, Issue 6, p.p. $629-638$

Dozet, N.D., Maćej, O.D.\& Jovanović, S.T. 2004, “Autohtoni mliječni proizvodi osnova za razvoj specifičnih, originalnih mliječnih prerađevina u savremenim uslovima”, Biotechnology in Animal Husbandry, vol. 20, no. 3-4, pp. 31-48

Kotler, P., Keler, K. (2006): Marketing menadžment, 12. izdanje, Data status, Beograd

Kotler, P. (1989): Upravljanje marketingom, Zagreb.

Ostojić, M.\& Topisirović, L. 2006, "Geografska oznaka porekla autohtonih sireva", Ekonomika poljoprivrede, vol. 53, no. 3, pp. 591-604.

Paraušić, Vesna, Kuzman, B., Arsenijević, Ž. (2007): Sajamska promocija poljoprivredno-prehrambenih proizvoda iz Srbije, Međunarodni naučni skup: Multifunkcionalna poljoprivreda i ruralni razvoj(II) - očuvanje ruralnih vrednosti, tematski zbornik, knjiga I, Beograd-Beočin.

Pieniaka, Z., Verbeke, W., Vanhonackera, F., Guerrerob, L., Herslethc, M. (2009): Association between traditional food consumption and motives for food choice in six European countries Appetite, Volume 53, Issue 1, p.p. 101-108.

Puškarić, A., Subić, J., Bekić, B. (2013): Regionalization as a Factor of Agriculture Development of the Republic of Serbia, International Journal of Sustainable Economies Management, 2(1), p.p. 46-54, January-March 2013.

Puškarić, A, Kuzman, B, Sarić, R. (2009): Promotion as factor of successful sale of organic produced vegetable on international market, 9th International Symposium - Prospects of agriculture and rural areas development, Publication series "Management, ekonomic engineering in agriculture and rural development", Vol. 9(2)/2009., University of agriculture sciences and veterinary medicine Bucharest, Faculti of management, economic, enginering in agriculture and rural development, Romania p.p. 11-12.

Radman, M., Kovačić, D., Kalit, S., Havranek, J., Kraljičković, J. (2004): Marketing autohtonog suhog sira zagrebačke okolice, Mljekarstvo, 54 (2) 93-107.

Rakić, B., Rakić, M. (2010): Pozicioniranje i diferenciranje tradicionalne srpske hrane, Economic Themes, Vol. 48 Issue 2, p.p. 253-263.

Vlahović, B., Puškarić, A., Nikolić, Danica, (2010): Istraživanje tržišta autohtonih prehrambenih proizvoda u Vojvodini, XV savetovanje o biotehnologiji, Vol. 15.(17),Zbornikradova Agronomski fakultet u Čačku, Univerzitet u Kragujevcu 
Vuković, P., Puškarić, A., Rajnović, Lj. (2013): Turizam i proizvodnja i plasman tradicionalnih lokalnih proizvoda, poglavlje u monografiji „Stanje i mogućnosti razvoja održive poljoprivrede i ruralnog razvoja u podunavlju“, Institut za ekonomiku poljoprivrede, Beograd, str. 142-167, ISBN 978-86-6269-024-1;

Zakon o oznakama geografskog porekla www.zis.gov.rs/upload/documents/pdf_en/ pdfogp/gop_zakon.pdf

Zavod za intelektualnu svojinu, Republika Srbija, Spisak oznaka geografskog porekla registrovanih u zavodu za intelektualnu svojinu,www.zis.gov.rs/prava-is/ознакегеографског-порекла/списак-огп.33.html 